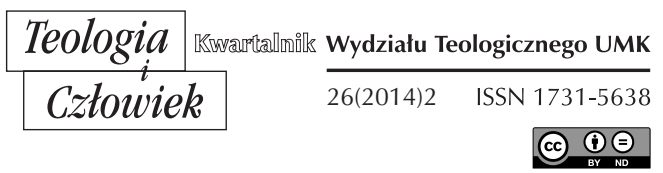

MARCIN SKŁADANOWSKI*

LUBLIN-DROHICZYN

\title{
CZY RODZINA PRZEMIJA? DEFINICJA I PRZYSZŁOŚĆ RODZINY WEDŁUG KOŚCIOŁA EWANGELICKIEGO W NIEMCZECH (EKD) W PERSPEKTYWIE EKUMENICZNEJ
}

DOI: http://dx.doi.org/10.12775/TiCz.2014.023

\section{WSTĘP}

Dnia 19 czerwca 2013 roku w Berlinie przedstawiciele luterańskiego Kościoła Ewangelickiego w Niemczech (Evangelische Kirche in Deutschland, EKD) zaprezentowali obszerny dokument zatytułowany Zwischen Autonomie und Angewiesenheit. Familie als verlässliche Gemeinschaft stärken. Eine Orientierungshilfe des Rates des Evangelischen Kirche in Deutschland (Między autonomia a zależnością. Umacnianie rodziny jako trwałej wspólnoty. Wskazania Rady Kościoła Ewangelickiego w Niemczech). Niektóre treści tego tekstu wywołały poruszenie $\mathrm{w}$ kręgach katolickich i prawosławnych, zarówno wśród teologów, jak i działaczy na rzecz promocji chrześcijańskiego rozumienia rodziny. Krytycy dokumentu zarzucają Radzie EKD, że zerwała z biblijnym obrazem rodziny, który przez wieki, pomimo podziałów wśród chrześcijan oraz związanych z nimi rozbieżno-

* Ks. dr Marcin Składanowski - teolog ekumenista i dogmatyk, prezbiter diecezji drohiczyńskiej, asystent w Katedrze Teologii Protestanckiej KUL i wykładowca w Wyższym Seminarium Duchownym w Drohiczynie. 
ści teologicznych, był jednomyślnie wspierany przez wszystkie Kościoły i Wspólnoty kościelne na Zachodzie i na Wschodzie. Wydaje się jednak, że krytycy podnoszą jedynie najbardziej kontrowersyjne stwierdzenia luterańskiego dokumentu ${ }^{1}$, nie wnikając $\mathrm{w}$ jego strukturę, podstawy teologiczne i społeczne oraz znaczenie dla życia kościelnego i społecznego zarówno w Niemczech, jak też w krajach zachodnich, w których dokonują się najsilniejsze zmiany kulturowe i obyczajowe dotykające życia rodzinnego. Konieczna jest pogłębiona analiza zarówno ostatniego tekstu, jak też innych wypowiedzi EKD, aby zrozumieć, w jaki sposób i dlaczego niemieccy luteranie zmieniają swoją doktrynę i praktykę duszpasterską.

W tym celu najpierw ukazane zostaną zmiany form życia rodzinnego w społeczeństwach zachodnich. Następnie poruszona będzie kwestia istnienia jednego chrześcijańskiego modelu rodziny. $W$ dalszej kolejności omówiona zostanie postawa EKD wobec nowych form życia rodzinnego, a w ostatnim etapie przedstawione będą ekumeniczne implikacje stanowiska EKD.

\section{RODZINA: ZMIANA CZY PRZEMIJANIE?}

Dokument Zwischen Autonomie und Angewiesenheit jest odpowiedzią EKD na zmieniające się formy życia rodzinnego w Niemczech. Niemniej jednak jego treść oraz wnioski mogą być zastosowane także do analizy społecznych przemian w innych krajach zachodnich ${ }^{2}$. Chociaż $\mathrm{w}$ drugiej połowie XX wieku i na początku XXI wieku zmiany te nabierają tempa, to jednak nie są one zjawiskiem całkowicie nowym. W zachodniej kulturze, inspirowanej chrześcijańskimi wartościami i wzorcami życia, model rodziny zmieniał się $\mathrm{w}$ ciągu wieków. Było to spowodowane wieloma czynnikami ekonomicznymi, politycznymi, społecznymi i religijnymi. Ekonomiczny rozwój zachodniej Europy doprowadził w ciągu ostatnich stuleci do przejścia od średniowiecznej gospodarki opartej na

${ }^{1}$ W artykule omawiany jest tekst Kościoła Ewangelickiego w Niemczech (EKD), będącego Wspólnotą luterańską. Stąd mówi się tu w uproszczeniu o „niemieckich luteranach", mając na myśli EKD. Należy jednak zwrócić uwagę na to, że do tradycji luterańskiej odwołuje się także niemiecki Kościół unijny (Vereinigte Evangelisch-Lutherische Kirche Deutschlands, VELKD) oraz konserwatywne Wspólnoty luterańskie.

${ }^{2}$ Zwischen Autonomie und Angewiesenheit. Familie als verlässliche Gemeinschaft stärken. Eine Orientierungshilfe des Rates der Evangelischen Kirche in Deutschland (EKD), Gütersloh 2013, s. 11-12. 
rolnictwie do gospodarki nowoczesnej, w której dominującą rolę odgrywają przemysł i handel. Ten rozwój sprzyjał także wzrostowi znaczenia miast. Specyficzne warunki życia miejskiego oraz postęp gospodarczy i techniczny zmieniły obraz rodziny, która przestała być w sposób konieczny związana z ziemią przekazywaną z pokolenia na pokolenie. Życie indywidualne, jak i wspólnotowe stało się bardziej dynamiczne. Jednakże brak przywiązania do ziemi rozluźnił więzi rodzinne i zakwestionował ich trwałość. Podobne znaczenie dla zmiany wzorców życia rodzinnego miały na Zachodzie czynniki religijne. Reformacja zaliczyła małżeństwo do porządku doczesnego, odrzucając jego sakramentalność3. To zaś ułatwiło dalszą ewolucję życia małżeńskiego oraz powstanie nowych coraz powszechniej akceptowanych wzorców rodziny. Jeśli małżeństwo podlega zasadniczo prawu doczesnemu, to istnieją także możliwości reinterpretacji jego znaczenia i istoty. Przemiany w religijnym rozumieniu małżeństwa doprowadziły wreszcie do współczesnych prób nowego zdefiniowania małżeństwa oraz rodziny, która już niekoniecznie - także zdaniem wielu teologów luterańskich - musi być oparta na trwałym związku mężczyzny i kobiety ani też nawet na jakimkolwiek związku mającym trwały charakter.

Niemieccy luteranie stwierdzają, że wielość zasad oraz wzorców życia rodzinnego jest $w$ kontekście europejskim zjawiskiem normalnym. $Z$ tego powodu zwracają uwagę, że wzór rodziny, niekiedy uważany za tradycyjny - rodzina oparta na małżeństwie kobiety i mężczyzny ze ścisłym podziałem ról - wcale nie ma charakteru nieprzemijającego i jako taki może być dzisiaj zakwestionowany również przez chrześcijan. Uważanie takich właśnie rodzin za "normalne" jest coraz mniej aktualne w świetle dokonujących się przemian ${ }^{4}$. EKD zwraca uwagę na główne przejawy dokonującej się transformacji życia rodzinnego we współczesnych społeczeństwach zachodnich.

Pierwszym z nich jest rosnący udział rodzin imigrantów w życiu społecznym. Społeczeństwa zachodnie, przyjmujące imigrantów w większości spoza europejskiego kręgu kulturowego, niewyznających także

${ }^{3}$ Commissione di studio nominata dalla Federazione luterana mondiale, dall'Alleanza riformata mondiale e dal Segretariato per l'unione dei cristiani, La teologia del matrimonio e i problemi dei matrimoni interconfessionali, 12, w: Enchiridion Oecumenicum. Documenti del dialogo teologico interconfessionale, t. 1: Dialoghi internazionali 1931-1984, red. G. Cereti, S. J. Voicu, Bologna 2004³ 1775.

${ }^{4}$ Zwischen Autonomie und Angewiesenheit, s. 11-12, 33. 
religii chrześcijańskiej, stają się coraz bardziej wielokulturowe. Imigranci przynoszą ze sobą także własne rozumienie rodziny oraz wzorce życia rodzinnego, które $\mathrm{w}$ niektórych przypadkach stanowią nowość wobec pojęć europejskich ${ }^{5}$.

Innym czynnikiem zmieniającym obraz życia rodzinnego jest coraz częściej zauważana i nagłaśniana przemoc. Nie znaczy to, że pojawiła się ona $\mathrm{w}$ rodzinach dopiero wraz $\mathrm{z}$ intensyfikacją zmian społecznych, nawet jeśli problemy ekonomiczne i kulturowe mogą być także przyczyną wewnątrzrodzinnych napięć i konfliktów. Zdaniem EKD ważne jest, że temat przemocy $\mathrm{w}$ rodzinach stał się $\mathrm{w}$ ostatnich latach znany i obecny w dyskusji publicznej ${ }^{6}$. Ujawnianie, także przez działaczy kościelnych, patologii trapiących rodziny wpływa bez wątpienia na coraz bardziej ambiwalentny odbiór tradycyjnego modelu życia rodzinnego w społeczeństwie. Okazuje się, że rodzina nie tylko może być środowiskiem wzrostu i rozwoju człowieka, jego wdrożenia do życia społecznego, formacji moralnej i religijnej, lecz - na co zwracają uwagę aktywiści zmierzający do reinterpretacji rodziny - może być miejscem opresji.

Szybkie tempo przemian ekonomicznych $w$ zamożnych krajach Zachodu prowadzi do rozwarstwienia społeczeństwa, sprawiając, że wiele osób dotyka ubóstwo. Ubóstwo, zwłaszcza związane z bezrobociem, stanowi z jednej strony trudność dla samych rodzin, z drugiej zaś przyczynia się do tego, iż młodzi ludzie rzadziej decydują się na założenie rodziny i wynikające stąd długotrwałe zobowiązania, mające także wymiar finansowy. To także sprawia - wraz z innymi elementami zmiany stylu życia - że spada liczba dzieci przychodzących na świat w rodzinach ${ }^{7}$.

Ważnym zjawiskiem $\mathrm{w}$ społeczeństwach zachodnich jest oddzielenie małżeństwa od rodziny ${ }^{8}$. Niekiedy pojęcia te bywały utożsamiane. Dokument EKD stwierdza, że w warunkach życia na Zachodzie konieczny związek małżeństwa i rodziny znajduje mniejsze uznanie społeczne. Świadczą o tym liczne przypadki zawierania związków partnerskich w krajach, których prawodawstwo na to pozwala, przy czym dotyczy do nie tylko par homoseksualnych. Ponadto więcej osób, żyjąc ze sobą, nie decyduje

5 Tamże, s. 17, 28.

${ }^{6}$ Tamże, s. $108-109$.

7 Tamże, s. 18, 23.

${ }^{8}$ Commissione di studio nominata dalla Federazione luterana mondiale, dall'Alleanza riformata mondiale e dal Segretariato per l'unione dei cristiani, La teologia del matrimonio, 6, 1769; F. Robertson-Elliot, Gender, Family and Society, Houndmills 1996, s. 22-23. 
się na jakąkolwiek formalizację związku . Również zauważalny jest spadek liczby osób, których małżeństwo jest błogosławione kościelnie ${ }^{10}$.

Innym elementem wpływającym na rozszerzenie społecznie akceptowalnych form życia rodzinnego jest występowanie związków partnerów tej samej płci, obecnie uregulowane przez prawodawstwo wielu państw. Związki te uznawane są za pełnoprawne rodziny, niezależnie od tego, czy prawodawstwo przyznaje im możliwość adopcji dzieci. EKD wskazuje, że w 2009 r. w związkach homoseksualnych w Niemczech (Regenbogenfamilien, „tęczowe rodziny”) wychowywało się już ok. 7000 tysięcy dzieci'11.

Obserwacje luteranów niemieckich na temat zmian modelu życia rodzinnego prowadzą do wniosku, że w ostatnich dekadach procesy przekształcenia rodziny znacznie przyspieszyły. Zarówno w prawodawstwie państwowym, w dyskursie publicznym, jak i w świadomości coraz większej grupy mieszkańców krajów zachodnich uznaje się możliwość alternatywnych - wobec tradycyjnego obrazu rodziny chrześcijańskiej wzorców życia rodzinnego. W tej sytuacji, w przeciwieństwie do Kościoła katolickiego, EKD czuje się zobowiązany do refleksji nad tym, czy nie nadszedł czas, aby także kościelną doktrynę oraz praktykę pastoralną poddać powtórnemu namysłowi i reformie, co umożliwiłoby aktywną obecność chrześcijan we współczesnych procesach społecznych oraz ułatwiłoby zaangażowanie osób żyjących w nowych, alternatywnych modelach rodzin, w życie wspólnoty kościelnej.

\section{CZY ISTNIEJE JEDEN CHRZEŚCIJAŃSKI MODEL RODZINY?}

Z katolickiego punktu widzenia rodzina winna opierać się na trwałym związku kobiety i mężczyzny, którego znakiem jest dla chrześcijan

9 Zwischen Autonomie und Angewiesenheit, s. 45; F. Robertson-Elliot, dz. cyt., s. $9-12$.

10 Zwischen Autonomie und Angewiesenheit, s. 25-26, 45.

11 Tamże, s. 27. Jednym ze współczesnych argumentów na rzecz jednakowej wartości związków osób tej samej płci oraz związku mężczyzny i kobiety jest fakt, że wiele osób żyjących w związkach homoseksualnych jest rodzicami - wychowują wraz z partnerem dzieci pochodzące albo z poprzedniego, heteroseksualnego, związku, albo też $\mathrm{z}$ adopcji $\mathrm{w}$ krajach, $\mathrm{w}$ których jest ona dopuszczalna, albo też poczęte $\mathrm{w}$ procedurze sztucznego zapłodnienia (por. R. Williams, Toward A Theology for Lesbian and Gay Marriage, w: Christian Perspectives on Sexuality and Gender, red. E. Stuart, A. Thatcher, Herefordshire-Grand Rapids 1996, s. 287). 
sakrament małżeństwa. Trwała wspólnota małżonków jest zdolna do przyjęcia i wychowania potomstwa. Taki model rodziny, mimo istnienia pewnych szczegółowych przypadków, takich jak małżeństwa, które nie mogą mieć własnych dzieci, jest uważany za typowo chrześcijański, zgodny z Ewangelią? ${ }^{12}$.

W obliczu zmian dokonujących się w społeczeństwach zachodnich luteranie niemieccy pytają jednak, czy wskazany wzorzec życia rodzinnego jest jedynym chrześcijańskim modelem rodziny. Udzielają na to pytanie odpowiedzi negatywnej, odwołując się do świadectwa biblijnego, w którym widzą wielość obrazów i sposobów rozumienia rodziny ${ }^{13}$. $\mathrm{Na}$ to spostrzeżenie wpływa także luterańska nauka o małżeństwie jako należącym do porządku ziemskiego (weltlich Ding), a zatem podlegającym prawom stanowionym przez człowieka ${ }^{14}$. Małżeństwo nie jest sakramentem, lecz wspólnotą pobłogosławioną przez Boga ${ }^{15}$. Zaklasyfikowanie go do porządku ziemskiego otwiera drogę do możliwych reinterpretacji oraz do rozszerzenia znaczenia małżeństwa i rodziny o związki osób oparte na innych zasadach.

Aby uzasadnić tę możliwość oraz brak jedności wizji rodziny w Biblii, EKD przypomina obrazy starotestamentowe, w których widzi rodziny jako luźne struktury patchworkowe (Patchwork-Konstellationen), złożone z osób dorosłych i dzieci pochodzących z różnych związków. Przywołuje się tu akceptowalną w Starym Testamencie poligamię, ale także nowotestamentowy przykład mieszkających razem sióstr Marii i Marty ${ }^{16}$. Dwuznaczne wspomnienie przez luterański dokument Marii i Marty (Łk 10,38-42) jest szczególnie intrygujące, zwłaszcza jeśli weźmie się pod uwagę kontekst wypowiedzi, która w ogólnym toku myśli prowadzi do akceptacji związków osób tej samej płci jako pełnoprawnych form życia rodzinnego. Tekst EKD sugeruje, że w obliczu rozmaitych form życia rodzinnego istotą rodziny, zgodnie z przekazem biblijnym, jest wspólne

${ }^{12}$ L. S. Cahill, Sex, Gender, and Christian Ethics, Cambridge 20056, s. 207-208.

${ }^{13}$ Zwischen Autonomie und Angewiesenheit, s. 13.

${ }^{14}$ Commissione di studio nominata dalla Federazione luterana mondiale, dall'Alleanza riformata mondiale e dal Segretariato per l'unione dei cristiani, La teologia del matrimonio, 12, 1775.

${ }^{15}$ Soll es künftig kirchlich geschlossene Ehen geben, die nicht zugleich Ehen im bürgerlichrechtliche Sinne sind? Zum evangelischen Verständnis von Ehe und Eheschließung - Eine gutachterliche Äußerung (EKD - Texte 101), Hannover 2009, s. 13-14.

${ }^{16}$ Zwischen Autonomie und Angewiesenheit, s. 56. 
życie osób powiązanych ze sobą różnymi związkami - kulturowymi, seksualnymi, relacjami pochodzenia rodzice-dzieci ${ }^{17}$.

Kościół Ewangelicki w Niemczech (EKD) uważa, że również w tekstach Nowego Testamentu wspólnota małżeńska i rodzinna jest ważna, niemniej jednak nie jest jedyną możliwą formą życia ${ }^{18}$. Wskazuje na to bezżenne życie samego Jezusa oraz Jego wezwanie, by Jego uczniowie szli za Nim, opuściwszy swoje rodziny (Mk 1,19-20). W Nowym Testamencie pierwszeństwo przed rodziną ma przynależność do rodziny Bożej i naśladowanie Jezusa. Aby wzmocnić tę tezę, luteranie niemieccy dopatrują się relatywizacji znaczenia rodziny $w$ zachowaniu dwunastoletniego Jezusa w świątyni jerozolimskiej (Łk 2,38-50) oraz w Jego relacji do Matki i braci (Łk 8,19-21) ${ }^{19}$. Warto zwrócić w tym ostatnim przypadku uwagę na to, że dokument nie odnosi się do innych tekstów ewangelicznych, które stosunek Jezusa do rodziny, a w szczególności do Matki, stawiają w odmiennym kontekście.

Kościół Ewangelicki w Niemczech (EKD) przychyla się zatem do argumentacji niektórych przedstawicielek teologii feministycznej, zgodnie z którą w Biblii nie można odnaleźć żadnego chrześcijańskiego modelu rodziny $^{20}$. Biblia nie daje podstawy do promocji jednego określonego wzorca. Taki wzorzec rzeczywiście pojawił się w chrześcijaństwie za sprawą samego Kościoła i jego struktur oraz praktyki duszpasterskiej. To Kościół, popierając rodzinę opartą na małżeństwie, uznał małżeństwo za wynikające $\mathrm{z}$ porządku stworzenia. Z odniesienia małżeństwa do biblijnego opisu stworzenia wynikało także - zdaniem niemieckich luteranów - uznanie przez Kościół mężczyzny za głowę rodziny. Reformatorzy nie dokonali gruntownej zmiany tradycyjnego modelu rodziny, mimo że małżeństwu odmówili sakramentalności. Jednakże przez sprzeciw wobec małżeństwa jako sakramentu Reformacja położyła większy nacisk na małżeństwo jako wspólnotę należącą do większej wspólnoty - zarówno społecznej, jak i kościelnej. W dalszym ciągu jednak nauka luterańska

17 Tamże, s. 57.

18 „In den Texten des Neues Testaments wird deutlich: Das Miteinander in Ehe und Familie ist wichtig, ist aber nicht die einzig mögliche Lebensform" (tamże, s. 60) [wyróżnienie autorów dokumentu].

19 Tamże, s. 60-61.

${ }^{20}$ R. Radford- Ruether, An Unrealized Revolution: Searching Scripture for a Model of the Family, w: Christian Perspectives on Sexuality and Gender, red. E. Stuart, A. Thatcher, Herefordshire-Grand Rapids 1996, s. 442-443. 
kładła nacisk na tradycyjny podział ról w małżeństwie, który w istocie podtrzymywał patriarchalny system społeczny ${ }^{21}$.

\section{POSTAWA EKD WOBEC NOWYCH FORM ŻYCIA RODZINNEGO}

Argumenty biblijne przeczące powszechnemu wciąż przekonaniu, że chrześcijaństwo ma do zaproponowania człowiekowi w każdym miejscu i w każdym czasie określony wzorzec życia rodzinnego, są dla EKD przesłanką do ponownej refleksji nad innymi sposobami realizacji życia rodzinnego. Jeśli rzeczywiście Biblia nie zawierałaby trwałego i jedynego możliwego modelu rodziny, lecz sama byłaby świadectwem nieustannego ewoluowania życia rodzinnego i bogactwa jego form, to chrześcijanie mogliby w nowych formach życia rodzinnego widzieć przejawy trwającej ewolucji. Ponadto, jeśli rzeczywiście model rodziny, który uważano za tradycyjny, byłby bardziej skutkiem oddziaływania doktryny i praktyki duszpasterskiej Kościoła, nie mając normatywnego zakorzenienia w prawie Bożym, można by się zastanawiać, czy Kościół nie powinien zmienić swojej doktryny i praktyki, dostosowując ją do nowych wymagań czasu.

Dokument EKD zauważa, że zadaniem Kościoła jest zwiększanie wrażliwości na istniejącą różnorodność form życia rodzinnego, w czym wyraża się kościelna świadomość zmian dokonujących się w życiu społecznymi i indywidualnym. Chodzi o to, aby ludzi żyjących w różnych układach rodzinnych zaangażować w życie kościelne ${ }^{22}$. Chrześcijańską zasadą łączącą wszystkie możliwe sposoby życia rodzinnego ma być partnerstwo. Takie rodziny, niezależnie od ich konkretnego kształtu i stylu życia, winny być wspierane w życiu politycznym, ekonomicznym, społecznym oraz kościelnym ${ }^{23}$.

\section{A. ZWIĄZKI OSÓB TEJ SAMEJ PŁCl}

Luteranie niemieccy wyrażają potrzebę wypracowania pewnej formy błogosławieństwa kościelnego, która odpowiadałaby nowym formom wspólnego życia. Możliwość kościelnego błogosławieństwa wynika

\footnotetext{
${ }^{21}$ Zwischen Autonomie und Angewiesenheit, s. 58-59.

22 Tamże, s. 132-133.

${ }^{23}$ Tamże, s. 145.
} 
$\mathrm{z}$ rozumienia tego aktu liturgicznego jako wyrazu usprawiedliwienia człowieka tylko z łaski, a nie na mocy jakichkolwiek uczynków. Akt liturgiczny nie ma charakteru sakramentalnego. Raczej wyraża zachętę skierowaną do ludzi, aby trwali w wierze. Jest także wyrazem bliskości Boga w życiu chrześcijan oraz miłości Bożej wobec każdego człowieka. Takie stwierdzenie prowadzi do postawienia pytania o możliwość błogosławienia przez Wspólnotę luterańską par homoseksualnych oraz równouprawnienia związków homoseksualnych w życiu kościelnym ${ }^{24}$.

W tym kontekście pojawia się wezwanie do ponownej refleksji nad tekstami biblijnymi, które potępiają akty homoseksualne jako grzech (Kpł 18,22; Rz 1,26-27). Konieczna jest także, zdaniem EKD, refleksja nad tym, czy w trwałych związkach osób tej samej płci nie ma elementów, które odpowiadają charakterystyce związku mężczyzny i kobiety. Człowiek od początku został stworzony do życia we wspólnocie (Rdz 2,18), której podstawą jest trwałość, miłość i wzajemna odpowiedzialność. W tej perspektywie można widzieć również w związkach osób tej samej płci, opartych na wzajemnej miłości i odpowiedzialności, realizację pierwotnego powołania człowieka ${ }^{25}$. Luteranie niemieccy przyłączają się tym samym do tego nurtu teologii zachodniej, który nie tylko opowiada się za kościelnym uznaniem związków osób tej samej płci, lecz również uznaje, że mają one z chrześcijańskiego punktu widzenia wartość równą związkowi mężczyzny i kobiety ${ }^{26}$. Podstawą akceptacji wartości związków osób tej samej płci oraz ich zrównania ze związkiem małżeńskim mężczyzny i kobiety jest antropologiczne przekonanie luteranizmu, zgodnie z którym człowieka nie można zredukować do jego cech biologicznych, lecz jego tożsamość i relacje do innych ludzi należy opisywać na różne sposoby ${ }^{27}$. To stanowić ma też punkt wyjścia w podejmowanych przez Kościoły krajowe dyskusjach na temat zmiany praktyki duszpasterskiej wobec par homoseksualnych oraz, co się z tym wiąże, na temat zmiany rozumienia rodziny. Te zmiany powinny nawiązywać do dokonujących

${ }^{24}$ Tamże, s. 53, 65-66.

${ }^{25}$ Tamże, s. 66.

${ }^{26}$ E. Stuart, Lesbian and Gay Relationships: A Lesbian Feminist Perspective, w: Christian Perspectives on Sexuality and Gender, red. E. Stuart, A. Thatcher, Herefordshire-Grand Rapids 1996, s. 305.

27 „Es zählt zu den Stärken des evangelischen Menschenbilds, dass es Menschen nicht auf biologische Merkmale reduziert, sondern ihre Identität und ihr Miteinander in vielfältiger Weise beschreibt" (Zwischen Autonomie und Angewiesenheit, s. 67) [wyróżnienie autorów dokumentu]. 
się przekształceń społeczno-obyczajowych oraz do idących za nimi reformami prawodawstwa państwowego, których celem jest zapewnienie sprawiedliwości wszystkim ludziom ${ }^{28}$.

\section{B. NOWE FORMY ZWIĄZKÓW MĘŻCZYZN I KOBIET}

Kościół Ewangelicki w Niemczech uważa, że fundament rodziny stanowi trwałość związku osób. Trwałość jest konstytutywna dla każdej wspólnoty ludzkiej, jednakże w rodzinie ma znaczenie szczególne z uwagi na dobro tworzących ją osób, a szczególnie dzieci' ${ }^{29}$. Warto zauważyć, że trwałość rodziny nie musi już koniecznie wyrażać się w sformalizowanej postaci związku małżeńskiego. Wynika to ze zobowiązania się przez EKD podjęcia nowego myślenia o rodzinie. Przypominając znaczenie troski o rodzinę, teksty EKD wskazują na to, że nie tylko małżeństwa są przedmiotem działalności duszpasterskiej, społecznej, edukacyjnej, kulturalnej i charytatywnej prowadzonej przez Kościół. Uwzględnienie przez struktury kościelne zmian zachodzących w życiu rodzinnym sprawia, że także inne formy wspólnego życia ludzi, takie jak związki partnerskie, możliwe w prawodawstwie części krajów europejskich, są rozważane jako uprawnione formy rodziny, które należy wspierać i umacniać30. Luteranie niemieccy są skłonni zaakceptować jako pełnoprawną rodzinę chrześcijańską związek łączący osoby, które z różnych powodów nie chcą zawierać małżeństwa ${ }^{31}$. Jak się wydaje, podstawa EKD wobec osób żyjących w różnych formach konkubinatu, także w zalegalizowanych formach związków partnerskich, jest konsekwencją uznania, że kościelne spojrzenie na rodzinę musi dostosować się do tendencji społecznych. Jest to także, w dalszej teologicznej perspektywie, skutek odmówienia małżeństwu sakramentalności i zaliczenia go do porządku doczesnego. Życie ludzi w różnych wspólnotach, w tym w rodzinie, wprawdzie również winno być podporządkowane prawu Bożemu, jednakże jego konkretne formy, jako ludzkie i przemijające, mogą być dostosowywane do wymagań czasu i miejsca.

${ }^{28}$ Tamże, s. 67-68; R. Williams, dz. cyt., s. 286-287.

29 Zwischen Autonomie und Angewiesenheit, s. 62.

30 Tamże, s. 141.

31 Soll es künftig kirchlich geschlossene Ehen geben, s. 23. 


\section{RADYKALNA ZMIANA STANOWISKA EKD}

Mówiąc o stosunku EKD do nowych wzorców życia rodzinnego, koniecznie należy zwrócić uwagę, że - jak to określił jeden ze współczesnych konserwatywnych teologów luterańskich - w dokumencie Zwischen Autonomie und Angewiesenheit dokonało się "rewolucyjne zerwanie $\mathrm{z}$ ciągłością nauki ewangelickiej oraz z powszechnymi przekonaniami chrześcijańskimi" ${ }^{\prime 2}$. Można w tym miejscu wskazać wielość wcześniejszych ekumenicznych deklaracji Wspólnot luterańskich, w tym również EKD, podtrzymujących tradycyjną chrześcijańską naukę o małżeństwie.

Wbrew tezom omawianego dokumentu luteranie wielokrotnie w dialogach na forum światowym i lokalnym podkreślali, że małżeństwo pochodzi z ustanowienia Bożego. W międzynarodowym dialogu katolicko-luterańsko-reformowanym zauważano, że z protestanckiego punktu widzenia wzór małżeństwa jest zawarty w Bożym planie zbawienia ${ }^{33}$. Jako takie łączy się ono ściśle z obietnicą zbawienia daną przez Boga człowiekowi ${ }^{34}$. W lokalnym dialogu prowadzonym przez Kościół Luterański w Australii (The Lutheran Church of Australia, LCA) ${ }^{35}$ stwierdza się, że małżeństwo zostało ustanowione przez Boga, Stwórcę ludzkości, „od początku"36. Zastanawiające jest to, że także wypowiedzi EKD szły w podobnym kierunku. W dialogu prowadzonym z katolickim episkopatem Niemiec przedstawiciele EKD deklarowali, że na podstawie świadectw biblijnych nauczają, że Bóg Stwórca ustanowił małżeństwo jako więź istotną dla człowieka. Małżeństwo było przez nich uważane za dar Boży ${ }^{37}$.

${ }^{32}$ Heillose Verwirrung, http://www.katholisch.de/de/katholisch/themen/gesellschaft/130627_familienpapier_ekd_kritik.php [29.07.2013].

${ }_{33}$ Commissione di studio nominata dalla Federazione luterana mondiale, dall'Alleanza riformata mondiale e dal Segretariato per l'unione dei cristiani, La teologia del matrimonio, 15, 1778.

${ }^{34}$ Tamże, 19, 1782.

${ }^{35}$ LCA jest zaliczany do konserwatywnych Wspólnot luterańskich, wiernych pierwotnej doktrynie luterańskiej. Należy do konserwatywnej Międzynarodowej Rady Luterańskiej, a nie do progresywnej Światowej Federacji Luterańskiej.

${ }^{36}$ Chiesa luterana d'Australia - Chiesa unita in Australia, Dichiarazione pastorale sul matrimonio, w: Enchiridion Oecumenicum. Documenti del dialogo teologico interconfessionale, t. 8: Dialoghi locali 1995-2001, red. G. Cereti, J. F. Puglisi, Bologna 2007, 836.

${ }^{37}$ Conferenza episcopale tedesca - Consiglio della Chiesa evangelica in Germania, Raccomandazioni comuni delle chiese per la preparazione al matrimonio fra partner di confessione diversa, 3.3., w: Enchiridion Oecumenicum. Documenti del dialogo teologico interconfessionale, t. 2: Dialoghi locali 1956-1987, red. G. Cereti, S. J. Voicu, Bologna 2000, 1224. 
Podobnie fundament biblijny małżeństwa EKD uznaje w dialogu prowadzonym z Kościołem prawosławnym w Niemczech ${ }^{38}$.

W wielu wypowiedziach luterańskich obecne jest także przekonanie o tym, że za małżeństwo może być uznany jedynie oparty na miłości, wierności i wyłączności związek mężczyzny i kobiety - i to bez względu na rozmaite zmiany społeczne i kulturowe, którym podlega rodzina. Mówią o tym luteranie w dialogu międzynarodowym, stwierdzając, że pomimo dokonujących się przemian nie można $\mathrm{w}$ żadnym razie rozumieć małżeństwa jedynie jako wielości różnych form życia, które nie miałyby wspólnego fundamentu. Jednym z elementów wspólnych i konstytutywnych dla małżeństwa, niezależnie od kontekstu kulturowego czy historycznego, jest to, jest ono związkiem mężczyzny i kobiety ${ }^{39}$. To stanowisko podtrzymują konserwatywni luteranie australijscy, stwierdzając, że małżeństwo stanowi związek mężczyzny i kobiety na całe życie, z wyłączeniem jakichkolwiek innych osób. Małżeństwo jest koniecznym fundamentem rodziny, a przez to również społeczeństwa ${ }^{40}$. Celem małżeństwa dla konserwatywnych luteranów australijskich jest zatem zjednoczenie mężczyzny i kobiety, aby stali się , jednym ciałem”, prokreacja oraz troska o wychowanie dzieci, jak też ochrona jednostki przed pokusami relacji seksualnych poza kontekstem związku małżeńskiego $^{41}$. Podobne stwierdzenia - kontrastujące z dokumentem Zwischen Autonomie und Angewiesenheit - formułował również EKD, zarówno w dialogu z Kościołem katolickim ${ }^{42}$, jak też z Kościołem prawosławnym ${ }^{43}$.

${ }^{38}$ Commissione della Chiesa ortodossa in Germania - Amministrazione dell'Ufficio ecclesiastico della Chiesa evangelica in Germania (EKD), Matrimoni fra cristiani e cristiane evangelici e ortodossi. Indicazioni per l'azione pastorale comune delle nostre chiese in Germania, 2, w: Enchiridion Oecumenicum. Documenti del dialogo teologico interconfessionale, t. 10: Dialoghi locali 2002-2005, red. G. Cereti, J. F. Puglisi, Bologna 2010, s. 685.

${ }^{39}$ Commissione di studio nominata dalla Federazione luterana mondiale, dall'Alleanza riformata mondiale e dal Segretariato per l'unione dei cristiani, La teologia del matrimonio, 9, 1772.

${ }^{40}$ Chiesa luterana d'Australia - Chiesa unita in Australia, Dichiarazione pastorale sul matrimonio, s. 836.

${ }^{41}$ Tamże, s. 843.

${ }^{42}$ Conferenza episcopale tedesca - Consiglio della Chiesa evangelica in Germania, Raccomandazioni comuni delle chiese, s. 1226.

${ }^{43}$ Commissione della Chiesa ortodossa in Germania - Amministrazione dell'Ufficio ecclesiastico della Chiesa evangelica in Germania (EKD), Matrimoni fra cristiani e cristiane evangelici e ortodossi, s. 685. 
$\mathrm{Z}$ tego krótkiego zestawienia wypowiedzi luterańskich, w tym również pochodzących z samego EKD, wynika, że najnowszy tekst stanowi zerwanie zarówno $\mathrm{z}$ tradycją doktrynalną i etyczną luteranizmu w ogóle, jak z wcześniejszymi wypowiedziami EKD. Zerwanie to wyraża się w całkowicie odmiennej ocenie biblijnych fundamentów małżeństwa, w zakwestionowaniu związku kobiety i mężczyzny jako jedynej formy małżeństwa oraz w ogólnej relatywizacji wartości małżeństwa dla życia chrześcijańskiego. Wydaje się, że przez tę zmianę EKD przyjął poglądy prezentowane przez część teologów chrześcijańskich związanych z antropologią i etyką opartą na zasadach teorii gender. $W$ tych środowiskach teologicznych coraz częściej wyraża się opinię, że chrześcijaństwo zbyt długo idealizowało małżeństwo ${ }^{44}$. Stawia się tezę, że niesłusznie Kościoły i Wspólnoty odnosiły małżeństwo do woli Bożej wobec człowieka, czego skutkiem był patriarchalizm, opresja kobiet oraz niemożliwość samodzielnego kształtowania własnego życia, zwłaszcza przez kobiety ${ }^{45}$. Środowiska teologiczne promujące zmianę chrześcijańskiego wzorca życia rodzinnego dążą natomiast do podważenia wartości małżeństwa przez pozbawienie go oparcia w wierze chrześcijańskiej, co w dalszej perspektywie ma doprowadzić do uznania przez Kościoły i Wspólnoty innych form związków międzyludzkich, takich jak związki osób tej samej płci, za tak samo wartościowe i zgodne $\mathrm{z}$ orędziem biblijnym ${ }^{46}$. Temu służy również promowanie definicji małżeństwa, której zacierają zróżnicowanie płciowe małżonków oraz zmieniają jego cele ${ }^{47}$.

${ }^{44}$ E. Stuart, dz. cyt., s. 305-306.

45 A. Webster, Revolutionising Christian Sexual Ethics: A Feminist Perspective, w: Christian Perspectives on Sexuality and Gender, red. E. Stuart, A. Thatcher, HerefordshireGrand Rapids 1996, s. 275.

${ }^{46}$ E. Stuart, dz. cyt., s. 305; A. Webster, dz. cyt., s. 277.

47 Znamiennym przykładem próby nowego określenia małżeństwa, w którym zróżnicowanie płciowe jest nieistotne, a zrodzenie i wychowanie potomstwa stanowi jedynie pewną opcję, jest definicja przedstawiona przez teologa episkopalnego (anglikańskiego): „Marriage is a life long union of two persons in heart, body, and mind, as set forth in liturgical forms authorized by this Church, for the purpose of mutual joy, for the help and comfort given one another in prosperity and adversity; sometimes also for the procreation and/or rearing of children, and their physical and spiritual nurture" (R. Williams, dz. cyt., s. 282). 


\section{EKUMENICZNE IMPLIKACJE STANOWISKA EKD}

Chociaż stanowisko EKD na temat rodziny wyrażone w ostatnim dokumencie Zwischen Autonomie und Angewiesenheit ma charakter wewnątrzkościelny i nie należy do dialogu ekumenicznego, to jednak wzbudziło duże kontrowersje poza samą Wspólnotą luterańską. Nie da się treści luterańskiego dokumentu oddzielić od problematyki ekumenicznej.

Decyduje o tym z jednej strony sam kontekst lokalny tekstu w Niemczech na wielu płaszczyznach, w tym również w kwestiach odnoszących się do małżeństwa i rodziny, konieczna jest luterańsko-katolicka współpraca, zwłaszcza wobec znacznej liczby małżeństw mieszanych wyznaniowo oraz w sytuacji dechrystianizacji dotykającej w podobnej mierze zarówno Wspólnotę luterańską, jak i Kościół katolicki. W tej sytuacji nie jest obojętne dla relacji międzykościelnych to, w jaki sposób jedna ze stron interpretuje zachodzące procesy społeczne oraz zmienia czy też dostosowuje do nich swoją doktrynę i praktykę duszpasterską. Zwłaszcza wobec podejmowanych przez Kościół katolicki, także w Niemczech, wysiłków mających na celu podkreślenie znaczenia małżeństwa mężczyzny i kobiety jako fundamentu rodziny chrześcijańskiej stanowisko luterańskie wydaje się krokiem utrudniającym dialog ekumeniczny oraz współpracę. Poważne, obecnie niemożliwe do rozwiązania problemy wiążą się tu z mocno wyrażoną relatywizacją znaczenia małżeństwa dla życia rodziny chrześcijańskiej oraz otwarciem drogi do akceptacji związków homoseksualnych jako rodzin w chrześcijańskim rozumieniu. Problem ekumeniczny stanowi tutaj nie tyle stosunek do zmian $w$ prawodawstwie podejmowanych przez władze państwowe, lecz o wiele bardziej akceptacja tych zmian w doktrynie i praktyce kościelnej, która prowadzi do radykalnej zmiany istoty rodziny chrześcijańskiej, popartej specyficznie interpretowanym orędziem biblijnym. Konsekwencją tego nie do zaakceptowania z katolickiego punktu widzenia - jest redukcja rodziny przez sprowadzenie jej istoty do wzajemnej odpowiedzialności osób. Z tego powodu nie są zaskakujące bardzo negatywne reakcje na tekst płynące ze strony niemieckiego Kościoła katolickiego ${ }^{48}$.

Tekst Zwischen Autonomie und Angewiesenheit ma także znaczenie dla dwustronnego katolicko-luterańskiego dialogu ekumeniczne-

${ }^{48}$ Die EKD, die Familie und der Zeitgeist, http://www.kath.net/news/41730 [29.07.2013]; Die deutschen Bischöfe sind sehr besorgt, http://www.katholisch.de/de/katholisch/themen/kirche_2/130620_familienpapier_interview_van_elst.php [29.07.2013]. 
go na forum światowym. Paradoksalnie niemal zbiega się on $\mathrm{w}$ czasie z ogłoszeniem w 2013 roku przez międzynarodową Luterańsko-Katolicką Komisję ds. Jedności długo zapowiadanego dokumentu na temat wspólnych katolicko-luterańskich obchodów 500-lecia Reformacji From Conflict to Communion. Lutheran-Catholic Commemoration of the Reformation in 2017. Ten obszerny tekst ma usprawiedliwić uczestnictwo Kościoła katolickiego w upamiętnieniu wystąpienia Marcina Lutra. Kładzie się w nim nacisk na pozytywne znaczenie Reformacji oraz na osiągnięcia dialogu ekumenicznego. Twórcy dokumentu - zauważając, że „prawdziwa jedność Kościoła może istnieć tylko jako jedność w prawdzie Ewangelii Jezusa Chrystusa" 49 - wskazują na to, że mimo istniejących trudności katolicy i luteranie są coraz mniej podzieleni. Zdaniem działaczy ekumenicznych katolicy i luteranie pięć wieków po Reformacji cieszą się wzrostem wzajemnego zrozumienia, współpracy i szacunku ${ }^{50}$. Ogłoszenie wkrótce potem przez EKD dokumentu wyrażającego poważną zmianę doktrynalną i duszpasterską oraz faktyczne zakwestionowanie chrześcijańskiego obrazu małżeństwa i rodziny stawia pod znakiem zapytania wartość tego typu ekumenicznych sformułowań ${ }^{51}$. Okazuje się niestety często, że za wzniosłymi słowami tekstów dialogowych, ukazujących wzajemne zbliżenie i porozumienie, stoją faktycznie coraz bardziej odmienne stanowiska, jeśli chodzi o wierność Kościoła słowu Bożemu, zwłaszcza w kwestiach społecznych i etycznych, oraz w tych sprawach, w których chrześcijanie muszą odnieść się do przemian społecznych, kulturowych i obyczajowych.

Stanowisko EKD w kwestii małżeństwa i rodziny wiele mówi o dzisiejszych trudnościach całego ruchu ekumenicznego. Dużą rolę odgrywają w nim dzisiaj nurty teologiczne związane z teorią gender, zmierzające do przedstawienia chrześcijańskiego uzasadnienia dla redefinicji lub marginalizacji znaczenia rodziny ${ }^{52}$. Właśnie coraz bardziej różniące się nauczanie etyczne oraz praktyka Kościołów i Wspólnot kościelnych

49 "The true unity of the church can only exist as unity in the truth of the gospel of Jesus Christ" (From Conflict to Communion. Lutheran-Catholic Commemoration of the Reformation in 2017. Report of the Lutheran-Roman Catholic Commission on Unity, Leipzig-Paderborn 2013, s. 7).

50 Tamże, s. 9.

51 Belastung für Ökumene, http://www.katholisch.de/de/katholisch/themen/ kirche_2/130625_interview_sattler_oekumene_familie.php [29.07.2013].

${ }^{52}$ M. Kurian, An Ecumenical Framework for a Liberative Human Sexuality, "The Ecumenical Review" 64 (2012), nr 3, s. 339-340. 
sprawia, że ruch ekumeniczny stara się poruszać kwestie niebudzące kontrowersji, takie jak sprawiedliwość społeczna, walka z rasizmem i innymi formami wykluczenia i marginalizacji czy też działalność na rzecz pokoju. Niemniej jednak w sprawach, które - tak jak zagadnienia małżeństwa i rodziny - również dotykają konkretnego życia wielu chrześcijan, a ponadto stanowią także obszar moralnego konfliktu między zobowiązaniami wynikającymi z wiary a powszechnymi tendencjami kulturowymi i obyczajowymi - ruch ekumeniczny okazuje się często bezsilny i zagubiony.

\section{WNIOSKI}

Stanowisko EKD na temat rodziny wyrażone w dokumencie Zwischen Autonomie und Angewiesenheit wskazuje na to, że luteranie niemieccy są wnikliwymi obserwatorami zjawisk zachodzących w życiu społecznym. Dokument jest szczegółową analizą zmian dokonujących się w społeczeństwie niemieckim. Szeroko wykorzystuje dane statystyczne, odwołuje się także do niemieckiego prawodawstwa. Poza wskazaniami teologicznymi i duszpasterskimi tekst EKD ma na celu również zajęcie stanowiska w toczącej się dyskusji, zwłaszcza jeśli chodzi o regulacje prawne dotyczące nowych form życia rodzinnego. Tak dokładne i wieloaspektowe studium świadczy o tym, że EKD chce być aktywnym uczestnikiem debaty społecznej w Niemczech, wysuwając postulaty nie tylko pod adresem struktur kościelnych i Kościołów krajowych, lecz również wobec wszystkich odpowiedzialnych za życie społeczno--polityczne kraju. Dokument EKD nie unika również obserwacji, które nie są z kościelnego punktu widzenia optymistyczne. Badając zasięg procesów zmiany społecznej, tekst otwarcie mówi o coraz słabszym społecznym oddziaływaniu struktur kościelnych oraz o coraz mniejszym związku rodzin (w różnych formach) z życiem kościelnym.

Pomijając szczegółowe rozwiązania kwestii prawnych i społecznych, stawiane jako propozycje dla struktur i organizacji politycznych w Niemczech, należy zwrócić uwagę na to, jaką rolę dokument EKD wyznacza strukturom kościelnym. Instytucje i organizacje kościelne mają zasadniczo do odegrania rolę społecznego i kulturalnego wsparcia ludzi żyjących w różnych formach wspólnoty rodzinnej. EKD akceptuje bez dyskusji zmianę definicji rodziny zachodzącą w niektórych uregulowaniach prawnych na Zachodzie. Co więcej, w celu podbudowania własnego stanowiska dokonuje reinterpretacji Pisma świętego i nauczania chrześcijańskiego na temat rodziny, aby dojść do wniosku, że małżeństwa nie można już rozumieć 
jako pochodzącego z Bożego ustanowienia (göttliche Stiftung)53. Zgodnie $\mathrm{z}$ tendencjami obyczajowymi i politycznymi dokument EKD faktycznie zrównuje z małżeństwem mężczyzny i kobiety związki osób tej samej płci oraz związki osób, które nie chcą zawrzeć małżeństwa, traktując je jako wyraz uprawnionej wielości i różnorodności życia rodzinnego. Towarzyszy temu duży nacisk na słabości rodzin tradycyjnie rozumianych, czemu służy obszerny opis patologii życia małżeńskiego, takich jak przemoc fizyczna czy seksualna. Charakterystyczne jest, że analiza zjawisk negatywnych dotyczy jedynie związków heteroseksualnych. W tekście, który między innymi ma za zadanie zachęcić Kościoły krajowe do wyrażenia w doktrynie i praktyce akceptacji dla nowych form życia rodzinnego, nie poddaje się analizie zachodzących w nich zjawisk patologicznych.

Wprawdzie dokument Rady EKD stanowi jedynie pomoc (Orientierungshilfe) i nie ma rangi zobowiązującej dla niemieckich luteranów, to jednak zawarte w nim stwierdzenia nie pozostawiają wątpliwości, że EKD dokonuje znaczącej zmiany nauki o rodzinie, do tego stopnia zmieniając czy też rozszerzając jej rozumienie, że faktycznie jakakolwiek oparta na słowie Bożym chrześcijańska etyka życia rodzinnego, mająca charakter normatywny, a nie jedynie opisowy, staje się niemożliwa. Trudny staje się też katolicko-luterański dialog na tematy etyki małżeńskiej i rodzinnej, jak też duszpasterska współpraca w dziedzinie wsparcia i promocji rodziny we współczesnym świecie.

Streszczenie. Czy rodzina przemija? Definicja i przyszłość rodziny według Kościoła Ewangelickiego w Niemczech (EKD) w perspektywie ekumenicznej. Dnia 19 czerwca 2013 roku w Berlinie przedstawiciele luterańskiego Kościoła Ewangelickiego w Niemczech (Evangelische Kirche in Deutschland, EKD) zaprezentowali obszerny dokument zatytułowany Zwischen Autonomie und Angewiesenheit. Familie als verlässliche Gemeinschaft stärken. Eine Orientierungshilfe des Rates des Evangelischen Kirche in Deutschland (Między autonomiq a zależnością. Umacnianie rodziny jako trwałej wspólnoty. Wskazania Rady Kościoła Ewangelickiego w Niemczech). Niektóre treści tego tekstu wywołały poruszenie w kręgach katolickich i prawosławnych. Krytycy dokumentu zarzucają Radzie EKD, że zerwała z biblijnym obrazem rodziny, który przez wieki, pomimo podziałów wśród chrześcijan oraz związanych z nimi rozbieżności teologicznych, był jednomyślnie wspierany przez wszystkie Kościoły i Wspólnoty kościelne na Zachodzie i na Wschodzie. W tym kontekście artykuł analizuje strukturę, teologiczne i społeczne podstawy dokumentu oraz jego znaczenie ekumeniczne.

Słowa klucze: EKD, luteranie, rodzina, małżeństwo, etyka, ekumenizm

${ }^{53}$ Zwischen Autonomie und Angewiesenheit, s. 13, 54. 
Abstract. Is the family passing by? The definition and future of the family according to the Evangelical Church in Germany (EKD) in an ecumenical perspective. On the 19th of June 2013 in Berlin representatives of the Lutheran Evangelical Church in Germany (Evangelische Kirche in Deutschland, EKD) have presented a comprehensive document Zwischen Autonomie und Angewiesenheit. Familie als verlässliche Gemeinschaft stärken. Eine Orientierungshilfe des Rates des Evangelischen Kirche in Deutschland (Between Autonomy and Dependence. Strengthening the Family as a Reliable Community. A Guide of the Council of the Evangelical Church in Germany). Some of the contents of the text have provoked a stir in Catholic and Orthodox circles. Critics of the document accuse the EKD Council of breaking with biblical model of the family, which for centuries - despite divisions among Christians - has been unanimously supported by Churches and Communities in the West and in the East. In that context, the article discusses the structure, theological and social grounds of the document and its ecumenical significance.

Keywords: EKD, Lutherans, family, marriage, ethics, ecumenism 